\title{
Regulatory reform: distinguishing between mutual-benefit and public-benefit entities
}

\section{Carolyn J. Cordery ${ }^{\mathrm{a}}$ and Dalice Sim $^{\mathrm{b}}$}

a: Aston Business School, Aston University, Aston Triangle, Birmingham, United Kingdom. P: +44(0) 0121204 3380; E: C.Cordery@aston.ac.uk

b: Dean's Department, University of Otago, P O Box 7343, Wellington South, New Zealand. E: Dalice.Sim@otago.ac.nz

\begin{abstract}
Purpose: The purpose of this paper is to analyse nonprofit regulation through comparing and contrasting mutual-benefit and public-benefit entities. It ascertains how these entities differ in size, publicness, tax benefits and whether these differences might suggest regulatory costs should be differentiated.

Design/methodology/approach: This mixed-methods study utilises financial data, submissions and interviews.

Findings: There are stark differences in these two types of regulated nonprofit entities. Members should be the primary monitoring agency/ies for mutual-benefit entities, but financial reports should be understandable to these members. Nevertheless, the availability of tax concessions, combined with the benefits of limited liability, suggest mutual-benefit entities should be regulated and monitored by government in a way sympathetic to their size.
\end{abstract}

Research limitations/implications: As with most research, a limitation is this study's focus on a single jurisdiction.

Practical implications: The differences in these entities' characteristics are important for designing regulation.

Social implications: Better regulation is likely to require a standard set of financial reporting standards. Government has the right to demand disclosures due to benefits mutual-benefit entities enjoy.

Originality/value: In comparison to studies utilising only public benefit data, this study uses unique datasets to compare public-benefit and mutual-benefit entities and presents nonprofit sector participant's perceptions of these differences in context. This enables analysis of how better regulation could be achieved.

Key words: charities, membership entities, nonprofit regulation, differentiated regulation. 


\section{Nonprofit Regulatory reform: distinguishing between mutual-benefit and public-benefit entities}

\section{Introduction}

Increasingly, regulation has become an important theme for research, particularly due to regulation's ability to drive behaviour (Fischer and Marsh, 2012). While the private and public sectors are frequently the focus of regulatory reform research, this is not so for the nonprofit sector. Regulation of nonprofit entities often aims to redistribute taxes by exempting these bodies. It also seeks to protect a donative and member-joining public whose support of nonprofit entities underpins national culture.

Nevertheless, nonprofit regulation has been criticised for its inconsistency. For example, in the United States (US) more than three decades ago, Hansmann (1986, p. 82) called for "lawmakers to review and reform the hodge-podge of organizational and regulatory law that applies to nonprofits to ensure that it is well-designed to assist nonprofits in serving [social] needs". While Breen et al. (2017) suggest 'waves' of regulation and self-regulation, the challenge of untangling regulation in different nonprofit segments has been largely ignored. Many regulatory statutes are longstanding (e.g. Cordery et al., 2016), but there is a push for Better Regulation, i.e. reforms that would reduce the impost of regulation on entities ((Bunea amd Ibenskas, 2017; De Jong and Van Witteloostuijn, 2015). Nevertheless, while a number of tools exist to rethink and improve regulation (Deighton-Smith, 2008), few studies of 'sunsetting' (repealing and reinvigorating older statutes) are available, a matter we seek to address.

This research concentrates on nonprofit regulatory issues, in particular (what regulatees perceive to be the onerous task of) financial filing (Flack and Ryan, 2005). It focuses on the 'sunsetting' of an Act through which mutual-benefit (membership) entities can take legal form and be registered, and the proposed requirements to require them to follow specific 
nonprofit accounting standards for their regulatory filings. The research addresses a gap in scholarship on nonprofit issues and public administration, which typically focuses on publicbenefit entities (for example, registered charities in Australia, New Zealand and the United Kingdom (UK) and 501(c)(3) entities in the US (Wagner, 2012)). Yet, mutual-benefit (membership) entities (such as incorporated societies) increasingly comprise a significant proportion of nonprofit entities. In many countries, nonprofit income is tax-exempt, although only public-benefit entities can release taxation rebates on donations received (Abramson $e t$ al., 2006; Weisbrod, 1989). ${ }^{1}$ This may be a reason that nonprofit mutual-benefit entities are regulated, but should they be held to similar public interest standards as public-benefit entities?

Research has analysed regulation of for-profit organisations, specifically that which seeks to reduce information asymmetry and also in terms of accounting standard-setting (Fischer and Marsh, 2012). Nonprofit public-benefit entities are increasingly regulated (Cordery et al., 2017), yet little is known about their counterpart mutual-benefit entities' finances $^{2}$ and whether regulatory reform should be more invasive or, following Better Regulation proposals, less. ${ }^{3}$

This research compares and contrasts nonprofit mutual-benefit and public-benefit entities, asking: (i) How do these entities differ in terms of revenue sources - are members largely in control?, (ii) What differences exist in the beneficiaries of mutual-benefit compared to public-benefit entities - are they public or private?, (iii) What is the extent of different entities' relative tax exemptions on surpluses and investments?, and (iv) What differences might suggest regulatory costs (e.g. red tape) should be differentiated?

\footnotetext{
1 Although some public-benefit entities have members, they differ from mutual-benefit entities due to their public-benefit mission (Cordery et al., 2017; Quarter et al., 2001; Wagner, 2012).

2 Many nonprofit entities are also unincorporated (Cordery et al., 2016; Hansmann, 1986), are not regulated and have fluid boundaries. Research into the finances of these arrangements is also necessary.

3 See section 2.3 for a discussion of these proposals.
} 
New Zealand is a useful site for research as it is an early and focused adopter of New Public Management (NPM) ideals, and Better Regulation reforms (Kelsey, 2010). It allows a natural experiment to answer the research questions, as the Incorporated Societies Act 1908 facilitates incorporation of a wide range of membership-based public- and mutual-benefit entities (Cordery et al., 2016). ${ }^{4}$ Yet, this Act is at odds to the Charities Act 2005 (updated in 2013) which now demands public-benefit entities follow new financial reporting standards. Hence, the Incorporated Societies Act 1908 is being redeveloped and proposes increased demands of mutual-benefit entities. As this research concentrates on the regulatory requirements for financial filing, it utilises a random sample of smaller $(<\mathrm{NZD} 2 \mathrm{~m}$ expenditure) mutual-benefit entities from the Incorporated Societies register, comparing their financial transactions to a similar sized sample of charities registered under the Charities Act 2005. In relation to the sunsetting of this Act, the research also analyses public submissions to the Exposure Draft of the Incorporated Societies Bill (Ministry of Business Innovation \& Employment, 2015) in particular, those related to the financial filing requirements. Ten interviews with experts (see Appendix 1) augment the submissions and expose preferences on mutual-benefit entities' regulatory filing obligations.

Recognising diffusion of regulatory policy and practice reforms (Breen et al., 2017) through such movements as Better Regulation, this research contributes to literature on nonprofit regulation and the potential impact of regulatory reform. It also highlights the failings of old legislation that needs more than incremental change.

First, the distinction between nonprofit public-benefit and mutual-benefit entities is made and secondly, reasons for regulation through disclosure, considered. The context and data is explained and findings presented. These suggest how a 'hodge-podge' of nonprofit regulation

4 Currently, 28\% of Incorporated Societies are registered charities (public-benefit entities) and $72 \%$ are mutual-benefit entities. Of registered charities, $37 \%$ were Incorporated Societies (the remainder are unincorporated charitable trusts, or limited liability companies (Cordery et al., 2016). 
can be reformed, through analysis of club theory (underpinning mutual-benefit entities) and the relative need to ensure public-benefit entities act in the public interest. The discussion and conclusion include limitations and future research opportunities.

\section{Literature Review}

\subsection{Categorising nonprofit entities}

This research focuses on membership organisations (a nonprofit subsector), particularly those choosing to take legal form. Buchanan's (1965) economic theory of club goods expects membership clubs are "a voluntary group deriving mutual benefits from sharing one or more of the following: production costs, the members' characteristics, or a good characterized by excludable benefits" (Sandler and Tschirhart, 1997, p. 335). The entity can (relatively cheaply) prevent non-fee-paying individuals from consuming club goods as opposed to freely-available public goods. Club goods may be enjoyed by one person at a time (rivalrous) or many (non-rivalrous). Club theory assumes that members, who receive the majority of the entity's benefits, should be the major funders as the club produces only incidental societal benefits (Buchanan, 1965; Sandler and Tschirhart, 1997). Potoski and Prakash (2007) further note that members also benefit from social externalities, such as credibility from belonging to a professional association, or following externally established rules.

Members also form nonprofit entities, as information asymmetry for non-members limits consumers' ability to assess service quality (Ben-Ner, 1986; Howell and Cordery, 2013). Public- and mutual- benefit entities can inspire users' trust in the quality of their goods when it cannot be directly observed (Ben-Ner, 1986; Hansmann, 1986). Further, public-benefit entities can redistribute societal wealth, to "reduce the burden on state funds, increase community resilience and encourage civil society" (Cordery et al., 2017, p. 2). 
Johnson (2014) notes a paucity of research into mutual-benefit entities (associations), although Fraussen and Halpin's (2016) Australian study discusses the diversity of national advocacy associations. They categorise associations as advocacy groups (citizens with issues, business and professional associations, and trade-unions) and 'other' (service delivery entities, leisure associations, political parties/think-tanks/research organisations who shape public policy). ${ }^{5}$ A variety of terms is used, with Steinberg (2007) classifying membership entities' missions as: instrumental (service-delivery) and expressive (cultural and advocacy).

Hansmann (1986) dichotomises entities by funding as: 'donative' (mainly donations), and 'commercial' (mainly goods and services). Alternative research on mutual-benefit entities' funding is scarce, although Cordery et al. (2017) largely confirm Hansmann's (1986) general categories, suggesting the categorisation drives entity control, and members should manage/regulate mutual-benefit entities. Quarter et al. (2001) also find Canadian mutualbenefit entities receive more commercial and less government revenues on average, than public-benefit entities. ${ }^{6}$ However, mutual-benefit entities (sports clubs) in many European countries receive up to ten percent of their funding from government (Sotiriadou and Wicker, 2013).

Hansmann (1986) also dichotomises nonprofit entities into: member-controlled (mutuals), or independently managed ('entrepreneurial'). Johnson's (2014) analysis of national associations across four different countries instead contrasts mutuals with professional associations (with no members). These studies do not analyse income, structure, or regulation. In summary, table 1 extends club theory to highlight the main differences between these entities.

These latter two may also be advocacy organisations, although Fraussen and Halpin (2016) omitted them.

6 Canadian mutual-benefit entities were deemed more democratic but have less volunteer participation than public-benefit entities. 
[Table 1 here]

Following prior research into public-benefit entity regulation (e.g. Cordery et al., 2017), this research asks: to what extent do mutual-benefit entity finances also suggest member or professional control? To more fully understand the activities (goods and services delivered), it further questions: what differences exist in the beneficiaries of mutual-benefit compared to public-benefit entities?

\subsection{Regulating nonprofit entities}

Charities (public-benefit entities) receive taxation concessions as they provide societal benefits and thus may assist in redistributing wealth (Fleischer, 2010; Hansmann, 1986). Hence charity regulation seeks to ensure they continue to act in the public interest. For example, Stewart and Faulk (2014, p. 630) highlight how requiring foundations to make certain distributions has succeeded in ensuring these public-benefit entities' "assets do not accumulate uncontrolled or directly benefit individuals related to the foundation".

Other nonprofit entities (including mutual-benefit entities) are also exempt from income taxes because they develop the arts, culture and social capital (Fleischer, 2010). ${ }^{7}$ Income tax benefits for nonprofit entities often link to a non-distribution constraint, and in many jurisdictions, these entities may also receive tax deductions/rebates from, for example, debt interest, sales and property tax (Abramson et al., 2006). Although allowing re-distribution of public funds to issues citizens also support, rebates can be problematic. Thiel and Mayer (2009) note that the German Federal Finance Office was concerned that tax relief was being extended to some sports clubs that had strong customer and for-profit orientations, rather

Nevertheless, Yetman and Yetman (2009) note these entities must pay tax on unrelated taxable revenues and chasing these revenues could risk an entity's nonprofit status. 
than nonprofit orientations. ${ }^{8}$ Nevertheless, regulatory oversight should extend beyond taxation (Breen et al., 2017).

Hansmann's (1986) concern that US nonprofit regulation is a 'hodge-podge' reflects contextually and temporally specific regulatory aspects. In the US, the Internal Revenue Service regulates both 501(c)(3) organisations (charities providing donors with taxdeductions) and 501(c)(4) organisations that may engage in lobbying but do not afford donors a tax deduction (Baber, Roberts, \& Visvanathan, 2001). Other nonprofit forms exist with varying regulation. In European jurisdictions, governments often regulate associations (as nonprofit entities), irrespective of their public- or mutual-benefit (DiMaggio and Anheier, 1990). Similarly in New Zealand, charities (public-benefit) are regulated within the Department of Internal Affairs (by Charities Services), and (non-charitable) incorporated mutual-benefit entities are regulated within the Ministry of Business, Innovation and Employment (by the Incorporated Societies Registrar) (Cordery et al., 2016). In Australia, while public-benefit entities must register and make disclosures with the Australian Charities and Not-for-profits Commission, mutual-benefit entities are subject only to variable State regulations.

Elsewhere, regulation focuses only on charitable (public-benefit) entities. For instance, the Canadian Crown Revenue Office requires charities to file, but the Not-for-profit Corporations Act 2010 does not require mutual-benefit entities to make financial disclosures to a regulator. ${ }^{9}$ Their members are expected to govern mutual-benefit entities, making them internally focused (Quarter et al., 2001). In the UK, charities are regulated jurisdictionally, but no organisational form exists for mutual-benefit entities (Cordery et al., 2016).

\footnotetext{
8 In some jurisdictions, donors to public-benefit entities also may receive tax deductions, but not for donations to mutual-benefit entities.

9 Information sourced from https://www.ontario.ca/page/guide-not-profit-corporations-act-2010
} 
Whether regulated or not, there is concern that entities may be victims of fraud (Tremblay-Boire et al., 2016), especially when they receive taxation concessions and the public purse is impacted. As regulatory monitoring should reduce fraud (including tax fraud), it is important to understand the potential tax foregone (for example, in respect of surpluses and investments).

\subsection{Disclosure and regulation}

Regulators seek to reduce information asymmetry, often requiring additional disclosures and especially financial statements (Breen, 2013; Solomons, 1978). Charity regulators typically require public-benefit entities to register, file financial returns, and, at certain levels, be audited (as presaged by Solomons, 1978). Calabrese's (2011) US study of public-benefit entities finds that audited entities provide more information, which is of better quality, highlighting monitoring's role in regulation (Stewart and Faulk, 2014).

The Better Regulation agenda suggests that regulation imposes burdensome administrative costs (Bunea and Ibenskas, 2017; De Jong and Van Witteloostuijn, 2015). Accordingly, techniques, including the Standard Cost Model and Regulatory Impact Assessments attend new regulation to ensure costs do not exceed the benefits (Coletti and Radaelli, 2013). Deregulation is also important for Better Regulation reforms, being typically achieved through resorting to markets (Bunea and Ibenskas, 2017). While a charities regulator can inform a 'donation market' (Cordery et al., 2017), such a market lacks the efficiency of for-profit markets.

Members have a self-regulatory role (Cordery et al., 2017); self-regulation can lead to statutory deregulation, or the state stepping-back (Breen et al., 2017). Yet, Bartle and Vass (2007, p. 902) highlight self-regulation's potential for regulatory capture, noting: "the state is critical for effective operation of [regulated entities'] accountability". Inferentially, members' regulation is more efficient when government further monitors goals such as income 
redistribution and fraud prevention. Further, despite economic and demographic change causing significant membership decline, the number and competition between mutual-benefit entities (in the UK) has increased (McCulloch, 2013). Putnam's (1995) US study suggests membership falls show declining civic-ness, but the literature has not considered whether these fewer members perceive they are co-regulators with the state. However, the evidence from the for-profit sector suggests that regulation cost, inconsistency and regulatory change may exacerbate these regulated entities' poor performance (De Jong and Van Witteloostuijn, 2015).

Where should the balance of regulation lie between increasing entities' disclosure requirements (allowing the public and regulator to monitor them to reduce fraud, support the tax base and protect members) and the consequent increased regulatory costs? While some regulatory reform has occurred since Hansmann (1986) stated it was a 'hodge-podge' in the US, is harmonisation the answer? What key differences (if any) exist between these entity types and do they suggest the need for differentiated re-regulation?

\section{Method}

The research utilises mixed methods which are described along with the research context.

\subsection{Context and quantitative data}

The quantitative analysis utilised two data sets from New Zealand regulators. The first was initially used by Cordery et al. (2017), being a stratified random sample of 829 smaller charities from the Charities Register. The New Zealand Charities Commission, established under the Charities Act 2005, was abolished as an independent Crown Entity in 2012 and is now named Charities Services, within the Department of Internal Affairs. Under the Charities Act 2005, entities that are deemed to be charities can be registered if they demonstrate that they act in the public interest and carry out charitable activities, that is the: relief of poverty, advancement of education, advancement of religion or other purposes beneficial to the 
community (Charities Act, 20052012 s.5(1)). Each charity must annually disclose standard financial information and file financial statements. Summary data and statements are downloadable and Charities Services publishes regular information of the size and reach of the approximately 27,000 registered charities in New Zealand. The majority of registered charities are small (with expenditure of less than NZD40,000). The sample taken in 2012 was stratified by population (those with less than NZD40,000 in expenditure and those with between NZD40,000 and NZD2,000,000 in expenditure) and, within each population stratum, by the sector that charities selected upon filing their financial statements. ${ }^{10}$ Public-benefit entities with zero expenditure were excluded from analysis, resulting in 796 entities in total for which the financial data was hand collected.

The second data set was taken from the Incorporated Societies register in 2015 and included only mutual-benefit entities that were not also registered charities. The Incorporated Societies Act 1908 allows nonprofit entities' members to enjoy the benefits of limited liability and perpetual succession, and almost 24,000 entities do so. Upon registering, incorporated societies must have at least 15 members. Entities are required to file financial statements of annual income and expenditure and the society's assets and liabilities at yearend (Incorporated Societies Act, 1908, s.23), although cash accounts are often filed. No audit is required unless the entity's constitution demands it. The Act was concerned to ensure members' funds were not diverted or lost (Cordery et al., 2016). Incorporated society's financial statements can be downloaded, but neither digital summaries nor detail about the population are available from the registrar. While the registrar sends reminders to entities that fail to file the required financial reports, the regulator is perceived to be relatively inactive. These two forms are summarised in table 2.

10 These two dollar amounts were used by the regulator when it was reviewing the requirements it sought to impose upon public-benefit entities. (NZD40,000 is approximately GBP21,400; NZD2 million is approximately GBP1,070,000.) 
[Table 2 here]

Unsurprisingly, reforms were begun to update the Act that is more than a century old, including to bring entities' financial reporting in line with current 'best practice'. The new Bill was foreshadowed by a Law Commission report, government's response and an Exposure Draft seeking feedback before the Bill was tabled in Parliament (Ministry of Business Innovation \& Employment, 2015; New Zealand Law Commission, 2013). The purposes of this Bill were to provide for incorporation of entities not seeking financial gain, to promote high quality governance "and recognise the principles that (i) societies are organisations with members who have the primary responsibility for holding the society to account; and (ii) societies are private bodies that should be self-governing and free from inappropriate Government interference; and (iii) societies should not distribute profits or financial benefits to their members" (Ministry of Business Innovation \& Employment, 2015, s.3(d)). Due to the change of Government in 2017, the reform has been delayed, but is still ongoing. ${ }^{11}$

This research sought to understand how mutual-benefit entities differ from registered public-benefit entities (charities), and what the impost of regulation should be. As the Incorporated Societies register is operated differently from the Charities register, a stratified sample was not possible, therefore a simple random sample was taken. First the registration number of all societies as at August $2015(23,695)$ was obtained, and any societies that were also registered charities were deleted $(6,847)$. Following this, the financial accounts for the prior year (up to 30 November 2015) were downloaded. Some were rejected as the entities had failed to file and had been struck off, other societies were new and had not yet filed statements. Also societies with zero expenditure were discarded (estimated at 3,910 across

\footnotetext{
${ }^{11}$ See: 'Next Steps' http://www.mbie.govt.nz/info-services/business/business-law/incorporated-societies
} 
the whole population). The final sample from the remaining population of 12,928 was 744 incorporated societies (5.75\% of the total number of registered incorporated societies).

\subsection{Descriptive data}

Table 3 shows the summary data on the expenditure break-points for the two samples. [Table 3 here]

\subsection{Qualitative data}

Two complementary qualitative data sets augmented the quantitative dataset. Ten interviews were undertaken in early 2016 with persons who were knowledgeable about the proposed changes to the Incorporated Societies Act and specifically the accounting (and therefore filing) changes proposed (see Appendix 1). Interviewees were provided with the results of analysis into the financial shape of incorporated societies compared to registered charities (see, for example Figures 1 and 2). Their views were sought on what regulation they perceived to be useful. Ethics approval was obtained for these interviews and each interview (lasting approximately one hour) was transcribed and made available to the interviewees. Interviewees also had access to a report on this study prepared for the accounting standards regulator before it was published, to detect possible errors.

In addition, submissions on the Exposure Draft of the Incorporated Societies Bill were analysed. Table 4 shows there were 114 submissions from a range of individuals and entities including on accounting and auditing issues. These submissions to this Bill (which were made available in March 2017) also covered numerous legal issues relating to incorporated societies' operations. This paper analysed submissions on the proposal that incorporated societies be required to make financial disclosures which comply with the same accounting standards mandated for registered charities. (Audit is not to be mandated.) Quotes reveal submitters' identities as the submissions are publically available. 
Table 4 shows that $90.6 \%(77 / 85)$ of those that commented on support or otherwise of the bill, did support it, albeit with suggestions on various clauses. Individuals, Sports and Culture Associations and Professional Associations were less likely to support it (ranging from $83 \%$ to $88 \%$ ) but 29 submitters did not make an overt statement of support or otherwise. Both accounting and audit issues were raised across the range of submitters.

[Table 4 here]

These two qualitative data sets were developed to augment the quantitative data which could show differences but not the opinions of regulated entities and their advisors. They were maintained and analysed using NVivo and codes and constructs derived from the literature reviewed.

\section{Results}

The literature expects that mutual- and public-benefit entities will differ in respect of: i) who receives benefits from the goods and services the entity produces; and ii) who funds the entity. However, the literature is ambiguous on whether: iii) taxation foregone is similar or differs between entities (which impacts whether regulation should protect public funds); and iv) whether other differences would suggest a different balance for the costs and benefits of regulation between mutual- and public-benefit entities (i.e. differentiated regulation).

\subsection{To what extent do members or the public receive benefits?}

First, the activities undertaken by these two samples of entities was assessed. Charities are required to select a main sector when they register as shown in table 5. This table provides this data for the population and sample of public-benefit entities. The sample of mutualbenefit entities was similarly analysed (no population data was available).

[Table 5 here] 
Table 5 shows significant differences in the activities undertaken by public-benefit and the sample of mutual-benefit entities $(\mathrm{p}<0.0005)$. Public-benefit entities are significantly less likely to select Culture/recreation, Law, Advocacy and politics, and Business and professional associations, but are significantly more likely to be involved in Education and research, Health, Social services, Grant-making/fundraising and volunteering promotion, Religion, and Other. This is unsurprising, as mutual-benefit entities in Culture/recreation, Law, Advocacy and politics, and Business and professional associations are likely not to be able to show a public-benefit focus to gain registration as a charity (mutual-benefit entity). There are no statistically significant differences between the two entity types selecting Environment or Development and Housing activities, with the former representing a small percentage of the sample.

Differences are also evident when analysing how these entities spend their funds whether primarily on members or public benefits. Table 6 shows that public-benefit entities spend significantly more resources on fundraising costs, grants, staff, overheads, and other (p, 0.0005). In contrast, mutual-benefit entities spend significantly more resources on member costs (i.e. affiliation fees, bad debts) and goods and services - typically delivered to members (p, 0.0005). These results were verified by using the Wilcoxon test which showed all differences were highly significant except for 'other' $(\mathrm{p}=0.012$, being significant).

[Table 6 here]

[Figure 1 here]

Figure 1 shows graphically the public nature of the majority of public-benefit entities' expenditure, compared to member-based expenditure in mutual-benefit entities. Revenue and expenditure items suggest members are largely in control of mutual-benefit entities. Therefore it is likely that allowing members to monitor these entities rather than government 
would be efficient (Cordery et al., 2017). A submitter concurred that members should selfregulate, stating:

Since for the most part, the smallest incorporated societies will be mutual-benefit organisations, there is no wider public policy interest in subjecting them to external financial scrutiny beyond what currently occurs. (Clan Keith in New Zealand)

While the notion of public-benefit from non-rivalrous goods was not raised, there was an acknowledgement that many mutual-benefit entities:

... have trading with members and trading with non-members. Tax [should be] paid on profits made on trading with non-members. Because [trading] is done on profit a lot of organisations would think: "do I have to split this out? Yes, I do.". (Al)

A further argument for splitting member and non-member expenditures (A2), is that:

... It is member's money and so they should be trying to spend it on their members, which is the point of the organisation. (A3)

Therefore, although non-members may receive incidental benefits (which they are charged for), members are the key beneficiaries of mutual benefit entities' activities.

\subsection{How do the finances show that entities are under professional or member control?}

Table 7 shows that public-benefit entities receive significantly more resources from public donations, rental, bequests, investments, and other $(\mathrm{p}<0.0005)$. In contrast, mutual-benefit entities receive significantly more resources from members, sales of goods and services, and sponsorship $(\mathrm{p}<0.0005)$. These results were verified by using the Wilcoxon test which showed all differences to be highly significant $(\mathrm{p}<0.0005)$, except for Rental revenue $(\mathrm{p}=$ 0.857). This suggests the differences in means are influenced by a few large outliers in the public-benefit entities.

[Table 7 here]

[Figure 2 here] 
Figure 2 shows graphically the public nature of the majority of public-benefit entities' funding compared to members' funding of mutual-benefit entities. An interviewee noted that, while mutual-benefit entities are membership groups:

... in contrast, a [public-benefit entity] is not a membership group generally, it is for a cause. So if you are looking at a membership group you need to look at what are the needs of the members, what do they want? (A4)

Indeed, they:

... are a bit different [from public-benefit entities], in that they have members and are accountable to them and they don't want the wider world poking about in their finances. (A3)

As the revenue streams show, mutual-benefit entities are mainly funded and therefore also run by members rather than the profesionals that run public-benefit entities funded by the public and government.

\subsection{What are mutual-benefits' potential tax exemptions compared to public-benefit}

\section{entities?}

As none of these entities is required to file tax returns that would allow a comparison of public benefits allowed to each type of entity, possible answers to this question must be inferred. An assessment of the surplus (and relevant tax) as well as the tax foregone on reserves, is used to proxy for the taxation comparison (using 28 percent which is the New Zealand company tax rate) as shown in table 8 . Mutual-benefit entities had a number of outliers, and therefore the Wilcoxon non-parametric test was used to compare the medians of the two groups, which were significantly different.

[Table 8 here]

Median surplus was significantly different between the mutual-benefit and public-benefit entities (Wilcoxon test, $Z=-3.120, p=0.002$ ). Mutual-benefit entities make smaller 
surpluses than public-benefit entities. The proxy for taxation foregone (the company rate of $28 \%$ of total surplus) also shows that mutual-benefit entities benefit by only a tenth of that enjoyed by charities in a similar expenditure band.

An assessment of reserves also shows significantly different median reserves between mutual-benefit and public-benefit entities (Wilcoxon test, $\mathrm{Z}=-2.880, \mathrm{p}=0.004$ ). The median for mutual-benefit entities was 9 months, compared to almost 10 months (9.95) for publicbenefit entities. Calabrese's (2013) study of US public-benefit entities noted median reserves of one month. Hence this study's entities are wealthier than his sample, but the mutualbenefit entities in this study have lower reserves than the public-benefit entities, suggesting less hoarding of the lower surpluses they make.

\subsection{What size differences might suggest regulatory costs should be reduced?}

Organisational size is an important measure for nonprofit research (Prentice, 2016) allowing comparisons - especially the assessment of the capacity of an entity to comply with regulatory requirements. Prentice (2016) noted that Gross Revenue, Gross Expenditure and Total Assets are the most commonly used size metrics. Table 9 shows that the population of the mutual-benefit entities is smaller than the public-benefit entities and includes Total Liabilities and Total Equity as further comparative size factors. The Wilcoxon test also supports this finding. It can be concluded that public-benefit entities are significantly larger than mutual-benefit entities.

[Table 9 here]

While the mutual-benefit sector includes large sports entities, professional bodies, industry training organisations etc. (A2), it is evident that, in general, mutual-benefit entities are considerably smaller than public-benefit entities, make smaller profits and hold lower reserves. This raises the question of whether they have the capacity or desire to be regulated 
as public-benefit entities are. One interviewee echoed the thoughts of many discussing compliance costs, relating on a mutual-benefit entity he was involved with:

... given the really tiny turnover .... What we have [in financial reporting] at the moment works, given our size. The thought of having to change that for a \$3-4000 turnover makes zero sense. My personal view would be to have a floor under which people would not have to comply. You would still have to lodge accounts with the registrar, however you can use any accounts you like. (C1)

Submitters also highlighted this concern. Eighteen favoured the proposals for all mutualbenefit entities to file and to follow the new public-benefit entity standards (these require accrual accounting above $\$ 125,000$ in expenditure and cash accounting below that). For example, those in favour of regulation requiring all entities to file using $21^{\text {st }}$ century standards, highlighted the benefits of incorporation:

...Federated Mountain Clubs has among its members small clubs which are Incorporated and have turnovers less than $\$ 5000$. While it may appear onerous to require a return from small societies, Federated Mountain Clubs believes that if a club wants the protection and advantages of being an Incorporated Society then the club must accept some duties associated with this privilege... (Federated Mountain Clubs)

Legal structure is a privilege providing various benefits and protections, and a choice. As such we see a basic level of financial accountability and transparency as a quid pro quo for this privilege. (RSM) (Accounting Firm)

Others recognised that often the current practice is poor, and requiring standardised reporting would benefit members:

... It is true that the imposition of reporting against the tiers is likely to cause worry and some difficulty for smaller clubs, particularly in the recruitment of Treasurers. However, the introduction of a financial reporting standard, if done correctly can improve the overall financial systems of a society and therefore ensure its membership is better informed... (Palmerston North Community Services Council) 
... While the financial reporting requirements might appear onerous for a society with a small turnover, Royal Federation believes there are greater advantages and protection associated with the requirements of the Bill... [and] ... a healthy, positive step towards accountable, transparent practices. Royal Federation supports the draft Bills' requirements that incorporated societies meet the same accounting standards as registered charities. (Royal Federation of NZ Justices Associations)

Such practices require internal controls and will likely reduce fraud, although not all agreed that mandating financial filing following public-benefit entity standards was necessary.

The requirements of the [public-benefit entities regulator] to record \& present receipts may suit for detecting fraud within charities, but must NOT be allowed to spread to noncharity [mutual-benefit entities], under the guise of being "generally accepted"... The majority of [these] are not registered charities, and should not have to jump through hoops that have little relevance. (Alec Knewstubb)

Twenty one submissions (out of 39) argued against all Incorporated Societies (mutual-benefit entities) being required to file according to the new standards, with 13 out of 39 suggesting reporting exemptions depending on size (ranging from $\$ 500$ (1), \$10,000 (1), \$15,000 (4), $\$ 20,000$ (2), $\$ 25,000$ (2), $\$ 30,000$ (1), $\$ 50,000$ (1), to $\$ 125,000$ (1) (an average of $\$ 28,115)$ ). As there was no statistically significant difference between mutual- and public-benefit entities reporting on an accrual basis, such comments indicate that mutual-benefit entities should be held to a lower level of public accountability:

We suggest that the financial reporting obligations under the bill are 'stepped' by member size and income, but that there be a provision for these to be negated by an acceptable proportion of members (either $75 \%$ or perhaps $90 \%$ if this is considered to be a special right or obligation) voting at an AGM. (Auckland District Law Society)

A [mutual-benefit entity] that only deals with and for the benefit of its members should not have to publically disclose its accounts. This is similar to the requirements of a private company that is not an issuer. (John Bullot) 
This latter submitter apparently opposes the Incorporated Societies Act (1908) which requires all entities to file 'accounts'.

With the new Act proposing greater reporting homogeneity, some submitters are also concerned that the benefits mutual-benefit entities receive are insufficient to require them to be subject to the same reporting requirements as public-benefit entities. An interviewee suggested that a mutual-benefit entity might therefore seek to register as a public-benefit entity to increase their taxation exemptions, especially if compliance are similar between mutual- and public-benefit entities (A3). Others are concerned that entities would go 'underground', noting:

... requiring [mutual-benefit entities] to meet accounting standards may create a disincentive for groups to incorporate. The first risk that this creates is that it is much harder to ensure the financial propriety of unincorporated societies. Secondly, the difficulty of operating an unincorporated society may cause individuals to eventually refrain from carrying out new and needed civil society functions. [We] would like to see more a flexible and voluntary accounting standards regime granted to non-charitable small incorporated societies (Park Legal Limited)

This sentiment was also commonly held by interviewees.

The law changes should help promote the [mutual-benefit] sector, and not unduly hamper it... [and create] ... a disincentive to forming these organisations, which provide many and varied benefits to their communities. Fundamentally it is a breach of the freedom of peaceful assembly and association, which should be possible without unnecessary compliance costs. (Volunteering New Zealand)

Consequently the wide support for no mandatory audit, as in the Bill's Exposure Draft, was unsurprising:

It is also pleasing to see that there is no requirement for audit of an organisations financial statements in the Bill. It will be a decision of members and funders of the organisation to determine this matter. (Stuart Burns) 
Nevertheless, an accounting firm believed that both public-benefit and mutual-benefit entities should be subject to audit:

... due to the fiduciary capacity that the governing body has over member's funds, we consider it appropriate for Incorporated Societies to be subject to the same audit or review requirements as registered charities. Effectively, there is separation between the "owners" and the governing body... Alternatively, consideration could be given to the current opt out provisions that are available for companies that have more than 10 shareholders. I.e. an Incorporated Society could opt out of the audit or review requirements if they obtain support each year from $95 \%$ or more of the members to do so. (BDO New Zealand)

Audit enables stakeholders to monitor, although some called for improved government monitoring (C2). Another community interviewee was less positive, noting:

To my mind, as I have heard it, a lot of the changes ... [are] actually to do with the workload of the government department administering them. It is always a worry that you solve their overwork problems by giving work to others. (C1)

This interviewee feels that new regulation will incur more regulatory burden on mutualbenefit entities. Nevertheless, 18 out of 39 fully supported mandatory filing following new financial reporting standards and a further 13 supported the use of these standards at differing revenue or expenditure levels.

\section{Discussion}

Nonprofit entities are important in society in part because they are said to increase cohesion and civic-ness (Putnam, 1995). Governments support public-benefit and mutual-benefit entities through providing tax exemptions (Abramson et al., 2006; Thiel and Mayer, 2009). Yet, these entities' regulation often differs. Wagner (2012) called for more research into nonprofit entities beyond those in the public-benefit entity sector. This research sought to 
understand differences between mutual-benefit and public-benefit entities and the specific aspects of mutual-benefit entities that regulation should acknowledge. It specifically considers the sunsetting of an Act for mutual-benefit entities and whether that Act's reinvigoration should increase filing requirements, specifically harmonisation with the accounting standards applicable to public-benefit entities.

This article analysed differences and similarities between the two entity types using quantitative and qualitative data from New Zealand, an early adopter of Better Regulation and NPM (Kelsey, 2010). It found that mutual-benefit entities' revenues are mainly from members, goods and services delivered to members and non-members, with donations being significantly less significant than received by public-benefit entities. Expenditure similarly emphasises member activities, rather than public fundraising and grants. While all financial flows cannot be entirely categorised by using Buchanan's (1965) club theory, they suggest a strong argument for member monitoring. Further, not only are the proxies for taxation foregone from mutual-benefit entities significantly lower than those for public-benefit entities, but these entities' size is also significantly different. Despite size-differences, currently both types of entities mainly use accrual accounting, which would suggest that new requirements would not be difficult to adhere to.

There is growing concern for regulation to address fraud, misuse of funds or to increase entities' reputations, including improving the donation 'market' (Cordery et al., 2017; Tremblay-Boire et al., 2016). Yet, mutual-benefit entities do not operate in a 'donation market', instead they operate in a 'member market' and search for legitimacy. Some of the New Zealand interviewees and submitters are aware of the benefits of incorporation, but they also note that the great majority of private limited liability companies (for-profit) in New Zealand are exempt from public filing. However, for-profit entities are required to file financial statements with the tax agency, whereas mutual-benefit entities do not (in New 
Zealand they file basic statements with another regulator - see table 2). The private nature of for-profit entities' filing is a further argument for mutual-benefit entities to experience lower levels of regulation than public-benefit entities.

The Better Regulation agenda and regulatory reform arises from citizens railing against red tape in the face of increased regulation, and that which is deemed to be unfair (Radaelli and Meuwese, 2009). In the reinvigorating of an Act that is over a century old, it could be expected that significant changes are required, particularly in public disclosures. This paper has shown that only $20 \%$ (8/39) submitters were completely against requiring mutual-benefit entities to provide greater reporting and at similar levels to those of public-benefit entities, with $80 \%$ in favour, but one-third (13/39) suggesting further relief for size. A large minority of submitters note the benefits of appropriate reporting standards for mutual-benefit entities to develop greater member accountability and better financial management; and that these benefits will assist members and the regulator to act in the public interest.

Others emphasized the member focus of mutual-benefit entities and the desire for selfregulation, especially as the current regulatory monitoring is deemed to be poor. Prior research has shown deterrence is a necessary aspect of good regulation (for example, Stewart and Faulk, 2014; Winter and May, 2001), but this is not occurring. In light of mutual-benefit entities' experience of very low levels of monitoring, some believe that renewed government interest in stronger regulation threatens their independence. Those who are unsupportive are reflected in the ethos of Better Regulation, that the costs of regulation should not exceed the benefits (Bunea and Ibenskas, 2017; Coletti and Radaelli, 2015; De Jong and Witteloostuijn, 2015).

Although those against greater filing obligations desire less government regulation, they may not be prepared to lose the benefits of limited liability and perpetual succession, or their tax relief on non-business surpluses. The quantitative analysis shows that mutual-benefit 
entities are mainly privately funded for the benefit of members (see club theory espoused by Buchanan, 1965; Sandler and Tschirhart, 1997); they are smaller than public-benefit entities on average; and therefore receive fewer tax exemptions. (Size is already recognised in regulation - see Table 2, column 2). It is these characteristics that would argue for lighter touch regulation, and certainly the theory would suggest that the members who fund mutualbenefit entities are best suited to regulate them, and that further regulation is not required.

Nevertheless, the new filing requirements have strong support and this is likely based on historic reasons, because the 1908 Act required all entities to file (Cordery et al., 2016). However, low levels of regulatory monitoring are likely to have reduced incorporated societies belief in regulation overall. The authors' analysis of filings suggests that membermonitoring of these mutual-benefit entities is also low.

If the government is to push for harmonisation of filing requirements (but not audit) between mutual-benefit and public=benefit entities, it needs to highlight the benefits of incorporation (limited liability and perpetual succession, along with the taxation benefits) (rather than self-regulation as seen in Prakash and Potowski, 2007). The regulator and regulatees must weigh up the costs to mutual-benefit entities of transitioning to modern financial reporting standards against the benefits to these entities, their members and the regulators themselves. At the very least, the new Act should consider including de-minimis requirements at which these entities do not have to file reports (as in England and Wales Cordery et al., 2016). This could be based on the average suggested by submitters $(\$ 28,115)$ or better still, the mean of smaller member-based entities $(\$ 12,000$. This is extrapolated from the mean of $\$ 11928$ from note 3, table 3).

While there are limitations in using a dataset from one country, the ability to compare and contrast mutual- and public-benefit entities in the same jurisdiction has opened a new area for future research. Analysing further the costs and benefits of regulation for both of 
these entity types will be useful not only in New Zealand, but also in other jurisdictions, especially since, as noted by Breen et al. (2017), there are strong similarities between regulatory regimes internationally. There are also limitations in the different dates of the quantitative data observations. Nevertheless, no external shocks were experienced in the interim which would suggest that the pattern of income and expenditure would be markedly different in the intervals between data collection.

\section{Conclusion}

Nonprofit research focuses almost exclusively on public-benefit entities, rather than other sub-sectors. This research has used unique datasets to compare public-benefit and mutualbenefit entities and present nonprofit sector participants perceptions of these differences in context. Buchanan's (1965) club theory recognises that mutual-benefit entities provide predominantly rivalrous goods and thus, are mainly funded and controlled by members who pay fees and fund the goods and services they receive (Ben-Ner, 1986; Hansmann, 1986). This New Zealand based research confirms this. However, governments may also provide members in mutual-benefit entities the benefits of limited liability, perpetual succession and tax exemptions, which invoke demands for accountability; therefore members could be expected to value an independent regulator. Prior research has not considered how mutualbenefit entities differ from public-benefit entities in terms of size and financial structure and how and to whom they should report and be regulated. These characteristics are in contrast to public-benefit entities which are more likely to redistribute social wealth, be mainly funded by donations and commercial services and be managed by professionals. Public-benefit entities are expected to act in the public interest. The differences between these characteristics are important for designing regulation.

This research argues that members should be the primary monitoring agency/ies for mutual-benefit entities, but that financial reports should be understandable to these members. 
Financial reporting preparation requires a set of standards, such as that already followed by public-benefit entities in New Zealand and recommended for mutual-benefit entities (through the Incorporated Societies Bill) as seen in this research. Homogeneous accounting standards are not an issue, but the differences in size and orientation (towards members) raises concerns amongst stakeholders to reduce the burden of new standards. While public-benefit entities must prepare accounts and file them with the charities regulator, a lower level of compliance is argued for mutual-benefit entities. Congruent with member monitoring, it would be reasonable for them to be required to maintain accounting records but not be required to file them (as in the UK and US for smaller public-benefit entities) unless they meet a de-minimis level of at least $\$ 12,000$. Government has the right to demand disclosures due to mutualbenefit entities' tax concessions, the benefits of their limited liability and perpetual succession. Nevertheless, this research has also found that mutual-benefit entities receive lower levels of taxation concessions than public-benefit entities and are smaller overall. This is a further argument in favour of a de-minimis for their filing in contrast to public-benefit entities that receive higher concessions. Other tools in the regulatory box include coregulation, to require filing but not publishing the reports (as in Japan) (Cordery and Deguchi, 2018), or to further simplify standards or requirements to reduce compliance costs.

By using club theory and comparison data, this research has shown support for differentiated regulation that has a theoretical base. This addresses the critique of 'hodgepodge' regulation (Hansmann, 1986) and should be aligned to Better Regulation ideals to reduce regulatory costs in comparison to benefits. It also maintains necessary government monitoring to ensure efficiency in income redistribution and fraud protection. International comparative research would also help in developing better measures of costs and benefits. 


\section{References}

Abramson, A.J., Salamon, L.M. and Steurle, C.E. (2006), "Federal spending and tax policies: their implications for the nonprofit sector”. In E. T. Boris \& C. E. Steurle, eds, Nonprofits and government: collaboration and conflict, (The Urban Institute Press, Washington DC), pp. 107-138.

Baber, W.R., Roberts, A.A. and Visvanathan, G. (2001), “Charitable organizations' strategies and program spending ratios". Accounting Horizons, Vol. 15, No. 4, pp. 329-343.

Bartle, I., and Vass, P. (2007), "Self-regulation within the regulatory state: Towards a new regulatory paradigm?” Public Administration, Vol. 85, No. 4, pp. 885-905.

Ben-Ner, A. (1986), “Nonprofit Organizations: Why do they exist in market economies?” In S. Rose-Ackerman, ed, The Economics of Nonprofit Institutions: Studies in Structure and Policy, (Oxford University Press, New York), pp. 94-113.

Breen, O.B. (2013), “The disclosure panacea: A comparative perspective on charity financial reporting." Voluntas: International Journal of Voluntary and Nonprofit Organizations, Vol. 24, No. 3, pp. 852-880.

Breen, O.B., Dunn, A. and Sidel, M. (2017), "Regulatory Waves: An Introduction." In O. B. Breen, A. Dunn, \& M. Sidel (Eds.), Regulatory Waves: Comparative Perspectives on State Regulation and Self-Regulation Policies in the Nonprofit Sector (Cambridge University Press, Cambridge), pp. 1-20.

Buchanan, J.M. (1965), “An economic theory of clubs.” Economica, Vol. 32, No. 125, pp. 114.

Bunea, A. and Ibenskas, R. (2017), “Unveiling patterns of contestation over Better Regulation reforms in the European Union”. Public Administration, Vol. 95, No. 3, pp. $589-604$.

Calabrese, T.D. (2011), "Public mandates, market monitoring, and nonprofit financial 
disclosures.” Journal of Accounting and Public Policy, Vol. 30, No. 1, pp. 71-88.

Calabrese, T.D. (2013), "Running on empty: The operating reserves of US nonprofit organizations." Nonprofit Management \& Leadership, Vol. 23, No. 3, pp. 281-302.

Coletti, P., and Radaelli, C.M. (2013), "Economic rationales, learning, and regulatory policy instruments." Public Administration, Vol. 91, No. 4, pp. 1056-1070.

Cordery, C.J., and Deguchi, M. (2018), “Charity registration and reporting: A crossjurisdictional and theoretical analysis of regulatory impact." Public Management Review, Vol. 20, No. 9, pp. 1332-1352.

Cordery, C.J., Fowler, C.J. and Morgan, G.G. (2016), “The development of incorporated structures for charities: a 100 year comparison of England and New Zealand.” Accounting History, Vol. 21, No. 2-3, pp. 282-303.

Cordery, C.J., Sim, D. and van Zijl, T. (2017), "Differentiated regulation: The case of charities." Accounting and Finance, Vol. 57, No. 1, pp. 131-164.

De Jong, G., and Van Witteloostuijn, A. (2015), "Regulatory red tape and private firm performance.” Public Administration, Vol. 93, No. 1, pp. 34-51.

Deighton-Smith, R., (2008), "What do we mean by "rethinking regulation"?" Australian Journal of Public Administration, Vol. 67, No. 1, pp. 41-56.

DiMaggio, P.J., and Anheier, H.K. (1990), “The sociology of nonprofit organizations.” Annual Review of Sociology, Vol. 16, No. 1990, pp. 137-159.

Fischer, M. and Marsh, T. (2012), "Two accounting standard setters: divergence continues for nonprofit organizations.” Journal of Public Budgeting and Financial Management, Vol. 24, No. £, pp. 429-465.

Flack, T., and Ryan, C. (2005), "Financial reporting by australian nonprofit organisations: Dilemmas posed by government funders." Australian Journal of Public Administration, Vol. 64, No. 3, pp. 69-77. 
Fleischer, M.P. (2010), "Theorizing the charitable tax subsidies: the role of distributive justice." Washington University Law Review, 87, 505-566.

Fraussen, B., and Halpin, D. (2016), “Assessing the composition and diversity of the Australian interest group system.” Australian Journal of Public Administration, Vol. 75, No. 4, pp. 476-491.

Hansmann, H.B. (1986), “The role of nonprofit enterprise.” In S. Rose-Ackerman, ed, The Economics of Nonprofit Institutions: Studies in Structure and Policy, (Oxford University Press, New York), Vol. 89, pp. 57-84.

Howell, B. and Cordery, C.J. (2013), "From Providers to PHOs: an institutional analysis of nonprofit primary healthcare governance in New Zealand". Journal of Public Budgeting, Accounting \& Financial Management, Vol 25, No. 1, pp. 4-40.

Johnson, E.W. (2014), “Toward international comparative research on associational activity: Variation in the form and focus of voluntary associations in four nations." Nonprofit and Voluntary Sector Quarterly, Vol. 43, No. 2S, pp. 163S-181S.

Kelsey, J. (2010), “'Regulatory Responsibility’: Embedded Neoliberalism and its Contradictions." Policy Quarterly, Vol. 6, No. 2, pp. 36-41.

McCulloch, A. (2013), "Cohort variations in the membership of voluntary associations in Great Britain, 1991-2007.” Sociology, Vol. 48, No. 1, pp. 167-185.

Ministry of Business Innovation \& Employment. (2015), Exposure Draft: Incorporated Societies Bill. Wellington, New Zealand: Commercial, Consumers \& Communications Branch Ministry of Business, Innovation \& Employmen. https://doi.org/ISBN 978-0908335-76-3

New Zealand Law Commission. (2013), A new act for incorporated societies (Vol. 31). Prakash, A., and Potoski, M. (2007), “Collective action through voluntary environtmental Programs: A club theory perspective.” The Policy Studies Journal, Vol. 35, No. 4, pp. 
$773-792$.

Prentice, C.R. (2016), "Why so many measures of nonprofit financial performance?

Analyzing and improving the use of financial measures in nonprofit research." Nonprofit and Voluntary Sector Quarterly, Vol. 45, No. 4, pp. 715-740.

Putnam, R.D. (1995), Bowling Alone: America's Declining Social Capital, (Princetown University Press,Princetown, NJ).

Quarter, J., Sousa, J., Richmond, B.J. and Carmichael, I. (2001), “Comparing member-based organizations within a social economy framework." Nonprofit and Voluntary Sector Quarterly, Vol. 30, No. 2, pp. 351-375.

Radaelli, C.M., and Meuwese, A.C.M. (2009), "Better regulation in Europe: Between public management and regulatory reform.” Public Administration, Vol. 87, No. 3, pp. 639654.

Sandler, T., and Tschirhart, J. (1997), “Club theory: Thirty years later.” Public Choice, Vol. 93, No. 3-4, pp. 335-355.

Solomons, D. (1978), “The politicization of accounting." Journal of Accountancy, Vol. 146(Nov.), pp. 65-72.

Sotiriadou, P., and Wicker, P. (2013), “Community sports clubs' responses to institutional and resource dependence pressures for government grants." Annals of Leisure Research, Vol. 16, No. 4, pp. 297-314.

Steinberg, R. (2007), “Membership Income”. In D. R. Young, ed, Financing Nonprofits: Putting Theory into Practice, (Altamira Press, Lanham, MD), pp. 121-156.

Stewart, A.J., and Faulk, L. (2014), “Administrative growth and grant payouts in nonprofit foundations: Fulfilling the public good amid professionalization?” Public Administration Review, Vol. 74, No. 5, pp. 630-639.

Thiel, A., and Mayer, J. (2009), “Characteristics of Voluntary Sports Clubs Management: a 
Sociological Perspective.” European Sport Management Quarterly, Vol. 9, No. 1, pp. 81-98.

Tremblay-Boire, J., Prakash, A.and Gugerty, M.K. (2016), "Regulation by reputation: Monitoring and sanctioning in nonprofit accountability clubs." Public Administration Review, Vol. 76, No. 5, pp. 712-722.

Wagner, A. (2012), “"Third sector" and/or "civil society": a critical discourse about scholarship relating to intermediate organisations." Voluntary Sector Review, Vol. 3, No. 3, pp. 299-328.

Weisbrod, B.A. (1989), "Rewarding performance that is hard to measure: The private nonprofit sector." Science, Vol. 244, No. 4904, pp. 541-546.

Winter, S.C., and May, P.J. (2001), "Motivation for Compliance with Environmental Regulations." Journal of Policy Analysis and Management, Vol. 20, No. 4, pp. 675-698. Yetman, M.H., and Yetman, R.J. (2009), “Determinants of nonprofits' taxable activities.” Journal of Accounting and Public Policy, Vol. 28, No. 6, pp. 495-509. 


\section{APPENDIX 1}

Table A1: List of interviewees and roles

\begin{tabular}{|l|l|l|}
\hline Label & Representing & Role \\
\hline A1 & Accounting profession & Partner Medium-sized firm \\
\hline A2 & Accounting profession & Partner Big 4 \\
\hline A3 & Accounting profession & Senior Manager Big 4 \\
\hline A4 & Accounting profession & Partner Medium-sized firm \\
\hline A5 & Accounting profession & Partner Medium-sized firm \\
\hline A6 & Accounting profession & Partner Big 4 \\
\hline C1 & Community representative & CEO Community peak body \\
\hline C2 & Community representative & CEO Association peak body \\
\hline C3 & Community representative & Capacity Builder consultant \\
\hline C4 & Community representative & Capacity Builder peak body \\
\hline
\end{tabular}


Table 1: Aspects of public-benefit and mutual-benefit entities from the literature

\begin{tabular}{|l|l|l|l|}
\hline Entity type & $\begin{array}{l}\text { Activities/Goods \& } \\
\text { Services }\end{array}$ & Funding & Control \\
\hline Public-benefit & $\begin{array}{l}\text { Mainly non-rivalrous } \\
\text { publicly focused }\end{array}$ & $\begin{array}{l}\text { Donations and } \\
\text { commercial }\end{array}$ & Professional and/or \\
\hline Mutual-benefit & $\begin{array}{l}\text { Predominantly } \\
\text { rivalrous, includes }\end{array}$ & Member fees and & Members and/or \\
& commercial & professional \\
\hline
\end{tabular}


Table 2: Comparing public-benefit entities to mutual-benefit entities

\begin{tabular}{|c|c|c|}
\hline Variable & $\begin{array}{l}\text { Public-benefit entities } \\
\text { (charities) }\end{array}$ & $\begin{array}{l}\text { Mutual-benefit entities } \\
\text { (membership-based) }\end{array}$ \\
\hline Membership requirement & 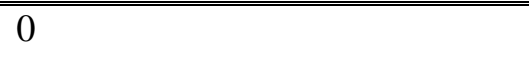 & 15 at registration \\
\hline Member Liability & Depends on form chosen & Limited liability \\
\hline Tax exemptions & $\begin{array}{l}\text { All income and also donee status } \\
\text { (exemption on donations) }\end{array}$ & $\begin{array}{l}\text { Member profits tax-exempt. No } \\
\text { donee status }\end{array}$ \\
\hline Distributions allowed? & Non-distribution constraint & Non-distribution constraint \\
\hline Regulator & $\begin{array}{l}\text { Charities Services (Department } \\
\text { of Internal Affairs) }\end{array}$ & $\begin{array}{l}\text { Incorporated Societies Registrar } \\
\text { (Ministry of Business, } \\
\text { Innovation and Employment) }\end{array}$ \\
\hline $\begin{array}{l}\text { Accounting requirements } \\
\text { for annual filing (all sizes } \\
\text { of entities) }\end{array}$ & $\begin{array}{l}\text { Cash for }<\text { NZD125,000 } \\
\text { expenditure p.a.; accrual ( } 3 \text { tiers } \\
\text { of increasingly complex } \\
\text { requirements) above that. } \\
\text { Assurance above } \$ 500,000\end{array}$ & Profit and loss and balance sheet \\
\hline
\end{tabular}


Table 3: Comparing the samples and the population of public-benefit entities and extrapolating the sample to the population for mutual-benefit entities

\begin{tabular}{|c|c|c|c|c|c|c|}
\hline \multirow{2}{*}{ Expenditure levels } & \multicolumn{2}{|c|}{ Public-benefit entities } & \multirow{2}{*}{$\begin{array}{l}\text { Sample } \\
\text { \% of Popn }\end{array}$} & \multicolumn{2}{|c|}{ Mutual-benefit entities } & \multirow{2}{*}{$\begin{array}{l}\text { Sample } \\
\%\end{array}$} \\
\hline & Sample & Population & & Sample & Population $^{2}$ & \\
\hline $\begin{array}{l}\text { Less than } \\
\text { NZD40,000 }\end{array}$ & $\begin{array}{l}379 \\
(52.4 \%)\end{array}$ & $\begin{array}{l}10,378^{1} \\
(53.5 \%)^{3}\end{array}$ & $3.65 \%$ & $\begin{array}{l}520 \\
(69.9 \%)\end{array}$ & $\begin{array}{l}9,043 \\
(69.9 \%)\end{array}$ & $5.75 \%$ \\
\hline $\begin{array}{l}\text { More than } \\
\text { NZD40,000 }\end{array}$ & $\begin{array}{l}417 \\
(47.6 \%)\end{array}$ & $\begin{array}{l}9,019 \\
(46.5 \%)^{3}\end{array}$ & $4.62 \%$ & $\begin{array}{l}224 \\
(30.1 \%)\end{array}$ & $\begin{array}{l}3,895 \\
(30.1 \%)\end{array}$ & $5.75 \%$ \\
\hline & $\begin{array}{l}796 \\
(100 \%)\end{array}$ & $\begin{array}{l}19,397 \\
(100 \%)\end{array}$ & $4.10 \%$ & $\begin{array}{l}744 \\
(100 \%)\end{array}$ & $\begin{array}{l}12,938 \\
(100 \%)\end{array}$ & $5.75 \%$ \\
\hline
\end{tabular}

1. This is the population of 11,282 less the estimated number of entities with zero expenditure as extrapolated from our sample.

2. The population was estimated from the data collected from the random sample of non-charitable entities with more than zero expenditure (as noted above).

3. The mean of sampled entities' expenditures for public benefit entities with less than $\$ 40,000$ in annual expenditure was $\$ 14,381$ (SD 11324) and mutual-benefit entities $\$ 11928$ (SD 10408). For those with more than $\$ 40,000$ in annual expenditure the relative means were \$262165 (SD349309) and \$228475 (SD325681) respectively 
Table 4: Categorisation of submitters on Incorporated Societies Bill and issues raised

\begin{tabular}{|l|l|l|l|c||c||}
\hline Type of submitter & Audit & Accoun & Support & Do not \\
issues & -ting & Bill & Total Number \\
issues & & Bill & of Submissions \\
\hline \hline Accounting \& Law Firms & 3 & 5 & 12 & 0 & 14 \\
\hline Professional Associations & 3 & 9 & 23 & 3 & 35 \\
\hline Sports \& Culture Associations & 0 & 10 & 15 & 3 & 26 \\
\hline Health \& Social Services & 0 & 7 & 10 & 0 & 12 \\
\hline Associations & & & & & \\
\hline Funder \& Capacity Builder & 0 & 1 & 6 & 0 & 15 \\
\hline Individual & & & & & \\
\hline Regulator/Government & 1 & 1 & 1 & 0 & 4 \\
\hline \hline Total & 10 & 39 & 77 & 8 & \\
\hline
\end{tabular}


Table 5: Classification of sample of mutual-benefit and public-benefit entities

\begin{tabular}{|c|c|c|c|c|c|c|}
\hline \multirow{2}{*}{ Main sector } & \multicolumn{2}{|c|}{$\begin{array}{l}\text { Public-benefit } \\
\text { Entity population }\end{array}$} & \multicolumn{2}{|c|}{$\begin{array}{l}\text { Public-benefit Entity } \\
\text { sample }\end{array}$} & \multicolumn{2}{|c|}{$\begin{array}{l}\text { Mutual-benefit } \\
\text { Entity sample }\end{array}$} \\
\hline & $\begin{array}{l}\text { Number } \\
\text { in sector }\end{array}$ & $\begin{array}{l}\% \text { in } \\
\text { sector }\end{array}$ & $\begin{array}{l}\text { Number } \\
\text { in sector }\end{array}$ & $\begin{array}{l}\% \text { in } \\
\text { sector }\end{array}$ & $\begin{array}{l}\text { Number } \\
\text { in sector }\end{array}$ & $\begin{array}{l}\% \text { in } \\
\text { sector }\end{array}$ \\
\hline 1. Culture and recreation & 3,026 & $13.78 \%$ & 162 & $20.40 \%$ & 538 & $71.64 \%$ \\
\hline 2. Education and research & 4,450 & $20.26 \%$ & 79 & $9.95 \%$ & 7 & $0.93 \%$ \\
\hline 3. Health & 1,565 & $7.12 \%$ & 86 & $10.83 \%$ & 1 & $0.13 \%$ \\
\hline 4. Social Services & 2,782 & $12.66 \%$ & 193 & $24.31 \%$ & 11 & $1.46 \%$ \\
\hline 5. Environment & 715 & $3.25 \%$ & 14 & $1.76 \%$ & 11 & $1.46 \%$ \\
\hline 6. Development \& housing & 1,877 & $8.54 \%$ & 109 & $13.70 \%$ & 93 & $12.38 \%$ \\
\hline 7. Law, advocacy \& politics & 0 & $0.00 \%$ & 0 & $0.00 \%$ & 22 & $2.93 \%$ \\
\hline $\begin{array}{l}\text { 8. Grant making/fundraising } \\
\text { \& voluntarism promotion }\end{array}$ & 773 & $3.52 \%$ & 89 & $11.21 \%$ & 1 & $0.13 \%$ \\
\hline 9. International & 43 & $0.20 \%$ & 0 & $0.00 \%$ & 0 & $0.0 \%$ \\
\hline 10. Religion & 3,428 & $15.61 \%$ & 34 & $4.28 \%$ & 3 & $0.40 \%$ \\
\hline $\begin{array}{l}\text { 11. Business and } \\
\text { professional associations }\end{array}$ & 0 & $0.00 \%$ & 0 & $0.00 \%$ & 64 & $8.52 \%$ \\
\hline 12. Other & 3,308 & $15.06 \%$ & 29 & $3.65 \%$ & 0 & $0.00 \%$ \\
\hline Grand Total & 21,967 & $100.00 \%$ & 795 & $100.00 \%$ & 751 & $100.00 \%$ \\
\hline
\end{tabular}


Table 6: Expenditure categories in mutual-benefit and public-benefit entities (percentages).

\begin{tabular}{|c|c|c|c|c|c|c|}
\hline Revenue Source & $\begin{array}{l}\text { Mutual- or Public- } \\
\text { benefit }\end{array}$ & $\mathbf{N}$ & $\begin{array}{r}\text { Mean } \\
\%\end{array}$ & $\begin{array}{r}\text { Std. } \\
\text { Deviation }\end{array}$ & $\begin{array}{r}\text { 2-sample } \\
\text { t test }\end{array}$ & $P$ value \\
\hline \multirow{2}{*}{$\begin{array}{l}\text { Fundraising } \\
\text { costs }\end{array}$} & Mutual-benefit & 751 & 0.88 & 5.09 & \multirow{2}{*}{$\begin{array}{r}t(1545)= \\
-5.308\end{array}$} & \multirow[b]{2}{*}{$<0.0005$} \\
\hline & Public-benefit & 796 & 3.34 & 11.71 & & \\
\hline \multirow[t]{2}{*}{ Grants made } & Mutual-benefit & 751 & 3.02 & 11.63 & \multirow{2}{*}{$\begin{array}{r}t(1369)= \\
-2.707\end{array}$} & \multirow[b]{2}{*}{$<0.0005$} \\
\hline & Public-benefit & 796 & 14.61 & 29.76 & & \\
\hline \multirow[t]{2}{*}{ Staff costs } & Mutual-benefit & 751 & 7.59 & 17.17 & \multirow{2}{*}{$\begin{array}{r}t(1545)= \\
-7.168\end{array}$} & \multirow[b]{2}{*}{$<0.0005$} \\
\hline & Public-benefit & 796 & 15.69 & 26.08 & & \\
\hline \multirow{2}{*}{$\begin{array}{l}\text { Overhead (incl. } \\
\text { financing, dep- } \\
\text { reciation, rent) }\end{array}$} & Mutual-benefit & 747 & 32.50 & 29.47 & \multirow{2}{*}{$\begin{array}{r}t(1545)= \\
-3.339\end{array}$} & \multirow[b]{2}{*}{$<0.0005$} \\
\hline & Public-benefit & 786 & 37.79 & 32.61 & & \\
\hline \multirow{2}{*}{$\begin{array}{l}\text { Goods and } \\
\text { Services }\end{array}$} & Mutual-benefit & 751 & 44.43 & 31.63 & \multirow{2}{*}{$\begin{array}{r}t(1545)= \\
15.657\end{array}$} & \multirow[b]{2}{*}{$<0.0005$} \\
\hline & Public-benefit & 796 & 20.86 & 27.52 & & \\
\hline \multirow{2}{*}{$\begin{array}{l}\text { Member costs } \\
\text { (affiliation, bad } \\
\text { debts) }\end{array}$} & Mutual-benefit & 751 & 7.73 & 15.19 & \multirow{2}{*}{$\begin{array}{r}t(1545)= \\
14.303\end{array}$} & \multirow[b]{2}{*}{$<0.0005$} \\
\hline & Public-benefit & 796 & 0.03 & .272 & & \\
\hline \multirow[t]{2}{*}{ Other } & Mutual-benefit & 751 & 3.84 & 11.94 & \multirow{2}{*}{$\begin{array}{r}t(1545)= \\
-3.339\end{array}$} & \multirow[b]{2}{*}{$<0.0005$} \\
\hline & Public-benefit & 796 & 7.68 & 19.64 & & \\
\hline
\end{tabular}


Table 7: Revenue sources in mutual-benefit and public-benefit entities (percentages).

\begin{tabular}{|c|c|c|c|c|c|c|}
\hline Revenue Source & $\begin{array}{l}\text { Mutual- or } \\
\text { Public-benefit }\end{array}$ & $\mathbf{N}$ & $\begin{array}{r}\text { Mean } \\
\%\end{array}$ & $\begin{array}{r}\text { Std. } \\
\text { Deviation }\end{array}$ & $\begin{array}{r}\text { 2-sample } \\
\text { t test }\end{array}$ & $P$ value \\
\hline \multirow[t]{2}{*}{ Public Donations } & Mutual-benefit & 751 & 20.53 & 27.13 & \multirow{2}{*}{$\begin{array}{l}\mathrm{t}(1423)= \\
-15.652, \mathrm{p}\end{array}$} & \multirow[b]{2}{*}{$<0.0005$} \\
\hline & Public-benefit & 796 & 47.12 & 38.96 & & \\
\hline \multirow[t]{2}{*}{ Bequests } & Mutual-benefit & 751 & 0.00 & 0.079 & $t(795)=$ & \multirow[b]{2}{*}{$<0.0005$} \\
\hline & Public-benefit & 796 & 0.38 & 4.73 & -2.187 & \\
\hline \multirow[t]{2}{*}{ Investments } & Mutual-benefit & 751 & 5.09 & 13.85 & \multirow{2}{*}{$\begin{array}{r}\mathrm{t}(1151)= \\
-7.720\end{array}$} & \multirow[b]{2}{*}{$<0.0005$} \\
\hline & Public-benefit & 796 & 13.98 & 29.18 & & \\
\hline \multirow{2}{*}{$\begin{array}{l}\text { Goods and } \\
\text { Services }\end{array}$} & Mutual-benefit & 751 & 39.75 & 33.02 & \multirow{2}{*}{$\begin{array}{r}\mathrm{t}(1523)= \\
11.401\end{array}$} & \multirow[b]{2}{*}{$<0.0005$} \\
\hline & Public-benefit & 796 & 21.15 & 31.04 & & \\
\hline \multirow[t]{2}{*}{ Rental } & Mutual-benefit & 751 & 2.75 & 10.71 & \multirow{2}{*}{$\begin{array}{r}\mathrm{t}(1369)= \\
-2.707\end{array}$} & \multirow[b]{2}{*}{$<0.0005$} \\
\hline & Public-benefit & 796 & 4.66 & 16.60 & & \\
\hline \multirow[t]{2}{*}{ Sponsorship } & Mutual-benefit & 747 & 3.05 & 10.63 & \multirow{2}{*}{$\begin{array}{r}\mathrm{t}(1149)= \\
4.729\end{array}$} & \multirow[b]{2}{*}{$<0.0005$} \\
\hline & Public-benefit & 786 & 0.96 & 5.87 & & \\
\hline \multirow[t]{2}{*}{ Members } & Mutual-benefit & 751 & 28.39 & 30.17 & \multirow{2}{*}{$\begin{array}{r}\mathrm{t}(1053)= \\
19.295\end{array}$} & \multirow[b]{2}{*}{$<0.0005$} \\
\hline & Public-benefit & 796 & 5.03 & 14.21 & & \\
\hline \multirow[t]{2}{*}{ Other } & Mutual-benefit & 751 & 2.97 & 11.28 & \multirow{2}{*}{$\begin{array}{r}t(1452)= \\
-3.680\end{array}$} & \multirow[b]{2}{*}{$<0.0005$} \\
\hline & Public-benefit & 796 & 5.49 & 15.50 & & \\
\hline
\end{tabular}


Table 8: Comparisons of surplus, taxation and reserves between mutual-benefit and public-benefit entities.

\begin{tabular}{|c|c|c|c|c|c|c|c|}
\hline Measure & $\begin{array}{l}\text { Mutual- or } \\
\text { Public-benefit }\end{array}$ & $\mathbf{N}$ & $\begin{array}{l}\text { Mean } \\
\text { NZ\$ }\end{array}$ & $\begin{array}{l}\text { Std. } \\
\text { Deviation }\end{array}$ & Median & $\begin{array}{l}\text { Wilco- } \\
\text { xon }\end{array}$ & $\begin{array}{l}P \\
\text { value }\end{array}$ \\
\hline \multirow{3}{*}{$\begin{array}{l}\text { Surplus } \\
\text { (\$) }\end{array}$} & Mutual-benefit & 751 & 3435.31 & 39794.48 & 308.94 & \multirow{3}{*}{$\begin{array}{l}Z= \\
-3.120\end{array}$} & \multirow{3}{*}{0.002} \\
\hline & Public-benefit & 796 & 34305.35 & 309206.83 & 1119.17 & & \\
\hline & Total & 1547 & 19319.31 & 223989.74 & 647.58 & & \\
\hline \multirow{3}{*}{$\begin{array}{l}\text { Proxy } \\
\text { taxation } \\
\text { at } 28 \% \text { on } \\
\text { surplus }\end{array}$} & Mutual-benefit & 751 & 961.89 & 11142.45 & 86.50 & \multirow{3}{*}{$\begin{array}{l}Z= \\
-3.120\end{array}$} & \multirow{3}{*}{0.002} \\
\hline & Public-benefit & 796 & 9605.50 & 86577.91 & 313.37 & & \\
\hline & Total & 1547 & 5409.41 & 62717.13 & 181.32 & & \\
\hline \multirow{3}{*}{$\begin{array}{l}\text { Reserves } \\
\text { (months) }\end{array}$} & Mutual-benefit & 751 & 35.71 & 122.27 & 9.01 & \multirow{3}{*}{$\begin{array}{l}Z= \\
-2.880\end{array}$} & \multirow{3}{*}{0.004} \\
\hline & Public-benefit & 796 & 662.33 & 11395.04 & 9.95 & & \\
\hline & Total & 1546 & 357.94 & 8175.32 & 9.57 & & \\
\hline
\end{tabular}


Table 9: Size comparisons between mutual-benefit and public-benefit entities.

\begin{tabular}{|c|c|c|c|c|c|c|}
\hline Size metric & $\begin{array}{l}\text { Mutual- or } \\
\text { Public-benefit }\end{array}$ & $\mathbf{N}$ & Mean NZ\$ & $\begin{array}{r}\text { Std. } \\
\text { Deviation }\end{array}$ & $\begin{array}{r}\text { 2-sample } \\
\text { t test }\end{array}$ & P value \\
\hline \multirow[t]{2}{*}{ Gross Revenue } & Mutual-benefit & 751 & 81207.47 & 210334.52 & \multirow{2}{*}{$\begin{array}{r}t(1159)= \\
-5.647\end{array}$} & \multirow[b]{2}{*}{$<0.0005$} \\
\hline & Public-benefit & 796 & 178856.29 & 437169.95 & & \\
\hline \multirow{2}{*}{$\begin{array}{l}\text { Gross } \\
\text { Expenditure }\end{array}$} & Mutual-benefit & 751 & 77544.97 & 204789.09 & $t(1452)=$ & \multirow[b]{2}{*}{$<0.0005$} \\
\hline & Public-benefit & 796 & 144550.94 & 281744.86 & -5.372 & \\
\hline \multirow[t]{2}{*}{ Total Assets } & Mutual-benefit & 751 & 165304.31 & 435868.82 & $t(871)=$ & \multirow[b]{2}{*}{$<0.0005$} \\
\hline & Public-benefit & 796 & 623051.54 & 2045964.35 & -6.166 & \\
\hline \multirow[t]{2}{*}{ Total Liabilities } & Mutual-benefit & 751 & 17270.87 & 72325.75 & $t(815)=$ & \multirow[b]{2}{*}{0.001} \\
\hline & Public-benefit & 796 & 99271.24 & 663363.17 & -3.466 & \\
\hline \multirow[t]{2}{*}{ Total Equity } & Mutual-benefit & 751 & 155468.07 & 535368.05 & $t(947)=$ & \multirow[b]{2}{*}{$<0.0005$} \\
\hline & Public-benefit & 796 & 503036.37 & 1768758.15 & -5.293 & \\
\hline
\end{tabular}




\section{Figure 1 Graph of expenditure categories}

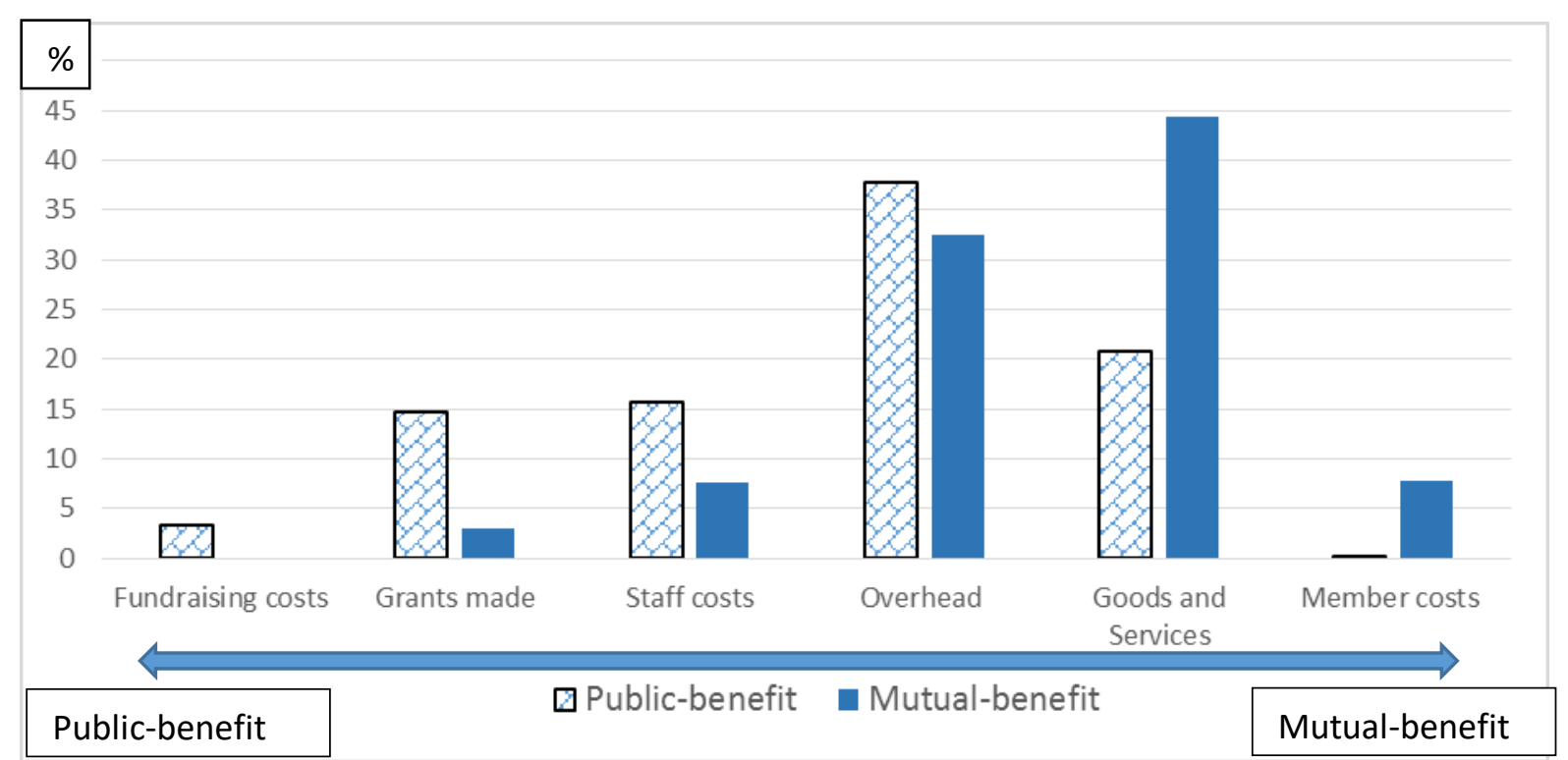


Figure 2: Graph of revenue sources

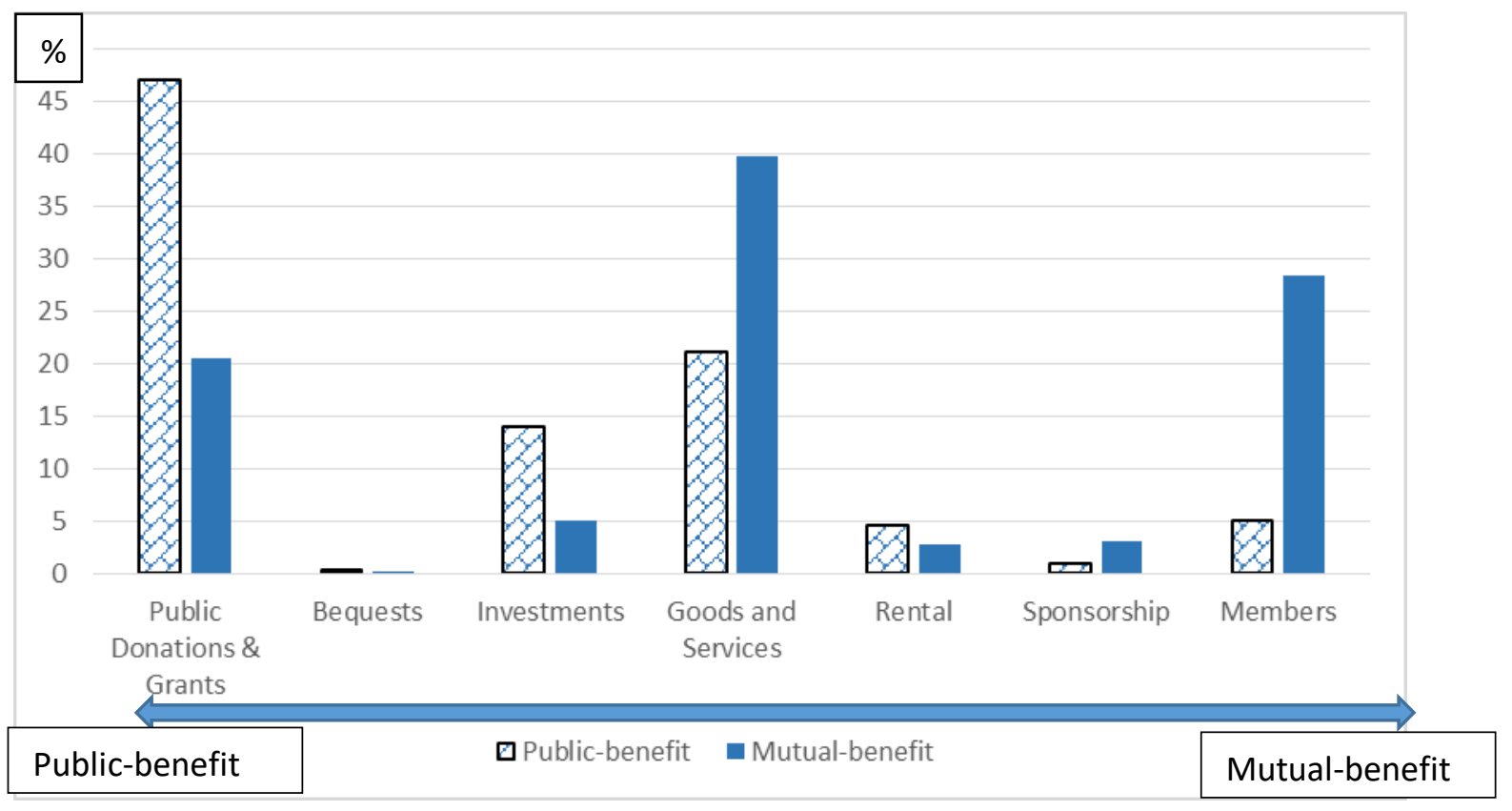

